\title{
Numerical Study of the Gap at the Base of the Bridge on the River Flow Parameters
}

\author{
Mohamadamin \\ Oyarhossein \\ Civil Engineering \\ Department, \\ University of \\ Aveiro, 3810-193 \\ Aveiro, Portugal
}

\author{
Vahid Khiali \\ Civil Engineering \\ Department, \\ University of \\ Aveiro, 3810-193 \\ Aveiro, Portugal
}

\author{
Kasra \\ Hosseinmostofi \\ Civil Engineering \\ Department, \\ University of \\ Aveiro, 3810-193 \\ Aveiro, Portugal
}

\author{
Mostafa Adineh \\ Civil Engineering \\ Department, \\ University of \\ Aveiro, 3810-193 \\ Aveiro, Portugal
}

\author{
Hamid Bayatghiasi \\ Civil Engineering \\ Department, \\ University of \\ Aveiro, 3810-193 \\ Aveiro, Portugal
}

\begin{abstract}
In this study, substrate surface channel and bridge piers is modeled by utilization of Ansys Fluent. Continuity and Momentum equations is solved and for the pressure-velocity linkage SIMPLE algorithm is utilized. In order to model turbulence due to relatively high Reynolds value, K- $\varepsilon$ is being used. Effect of wall shear stress, velocity magnitude and static pressure is being investigated at different heights thorough substrate longitudinal lines. It was found that different heights of longitudinal lines won't affect static pressure, while it affects velocity magnitude and wall shear stress significantly.
\end{abstract}

Keywords: Bridge, Scour, Shear stress , Numerical Study

\section{INTRODUCTION}

For bridges with piers sitting in the water, flood waters can cause scour at bridge foundations, undermining bridge structures by partially removing the supporting soil. The exposure of bridge foundations reduces the lateral load bearing capacity of bridges as well as the buckling resistance of pile foundations [1,2]. In addition to the reduced bridge capacity and stability, the exposure of bridge foundations also increases the flow-induced load acting on the bridge. Thus, a bridge that is subjected to scour becomes vulnerable in floods. For example, a large number of bridges in Taiwan have been significantly damaged due to the combined effects of scour and flow-induced loads since 2000 [3]. The damage includes tilted and tipped-over piers, dropped superstructures, pier settlements, and partial and complete collapses. The behavior of scoured bridges under flood conditions involves complex interactions between bridge structures, pile foundations, soils, and water. In recent years, a number of studies [4-12] have attempted to study the behavior of scoured bridges under flood conditions. Most of these studies have been conducted based on relatively simplified models or indirect approaches. Bennett et al. [4] studied the effect of scour depths on the behavior of a bridge pile group under flood conditions. McConnell and Can [5] investigated the influence of scour on the strength capacity of the substructure and superstructure of the Indian River Inlet Bridge. Lin et al. [6] proposed an integrated technique for analyzing bridge substructures and superstructures in an iterative fashion in order to assess the effect of scour on the bridge system performance. Ghadami et al. [38] studies the role of sensors in determining the structural health of the bridges along with efficient methods for sensor data transmission. Klinga and Alipour [7] investigated the influence of different types of scour, including local scour, general scour, aggradation, and degradation on the behavior of bridges. A common strategy for enhancing the lateral resistance of scour-critical pile supported bridges is to install additional piles to bridge foundations. However, the increased number of piles also adversely affects the bridge safety by inducing magnified flow-induced loads acting on the bridge. Hughes et al. [8,9] evaluated the influence of scour on the performance of bridges with pile bents and investigated the effectiveness of bracing systems for mitigating the scour damage to bridges. The performances of $\mathrm{X}$ - braced bents with and without a horizontal bracing strut were examined. During flood events, authorities are faced with the challenge of making appropriate decisions regarding traffic control on bridges. If bridges can remain open, they can serve an important role in disaster recovery. Nevertheless, significant casualties and property loss can occur if bridges in danger of collapse are not closed in a timely Scour is the most serious waterway problem at which greater than $60 \%$ of the reported failures can be attributed to it [27]. There are many reports about bridges failure around the world due to scouring $[10,17]$. The mechanism of scouring around a bridge pier is very complex and has been reported by various investigators $[9,15,16]$ and [5]. Abdelhafiz [3] studied the effect of pier shape and spacing on energy loss and scour around bridge piers. It was found that the maximum scour occurs upstream of the pier and the depth of scour hole increases as tail Froude number increases. Fotherby and Jones [8] used collars around bridge pier for reducing and controlling local scour depth. The authors recognized the potential usage of both a collar and a footing for scour reduction. In [37] Shahri et al. conducted a numerical study of sediment flow using Flow-3D Experimental studies were applied using piers provided with slots and collars under different flow conditions by Kumar [13]. Kumar et al. [14] studied the efficiency of slots with different lengths and angles of attack. It was concluded that a slot can be effective in reducing scour, particularly if it extends into the bed, and that the slot is practically ineffective if the approach flow has a high obliquity with respect to the slot. Zarrati et al. [29] worked on the application of a collar to control the scouring around rectangular bridge piers having a rounded nose. It was found that collar effectiveness improves as the collar becomes wider and as the level at which it is positioned on the pier becomes lower. Reduction of local scour in the vicinity of circular bridge pier groups

using collars and riprap was studied by Zarrati et al. [30] The effect of triangular collar around bridge pier was studied experimentally by Mohamed et al. [19]. Different shapes and compound bridge piers. EL-Ghorab [6] studied 
experimentally the local scour depth around bridge piers provided with slots. Torabi et al. at 2019 by using Finite Volume Method investigated the effect of geometry parameters on erosion and sedimentation in channel's junction [31]. The effect of pile cap thickness on the temporal evolution of the maximum scour depth and the development of equilibrium conditions was investigated by Ferraro et al.[7]. Sheppard et al. [26] performed an evaluation of the existing equations for the local scour at bridge piers. Nordila et al.[22] studied the local scour depth at wide bridge piers. In addition, laboratory studies of sacrificial piles for pier scour protection are reported by Shen et al. [25], Chang and Karim [4], Paice and Hey [23], and Singh et al. [27]. These studies showed up to $50 \%$ scour reduction due to the presence of the sacrificial piles. Laboratory studies on the use of sacrificial piles as a pier scour countermeasure are reported by Melville and Hadfield [18].

\section{TRANSPORT EQUATIONS IN}

\section{TURBULENCE MODEL $\boldsymbol{k}-\boldsymbol{\varepsilon}$}

All Realizable K- $\varepsilon$ is being utilized to consider the effect of turbulence. Each term of $\mathrm{K}$ and $\varepsilon$ is being illustrate separately by Zeidi et al. [32-34]. In the mentioned study the appropriate conditions in which realizable $\mathrm{K}-\varepsilon$ turbulence model is needed to used is clarified comprehensively by utilization of finite volume scheme.

$$
\begin{array}{cl}
\frac{\partial}{\partial t}(\rho \kappa)+\frac{\partial}{\partial x_{i}} & \left(\rho \kappa u_{i}\right) \\
& =\frac{\partial}{\partial x_{i}}\left[\left(\mu+\frac{\mu_{t}}{\sigma_{k}}\right) \frac{\partial \kappa}{\partial x_{j}}\right]+G_{k}+G_{b} \\
& -\rho \varepsilon-Y_{m}+S_{k} \\
\frac{\partial}{\partial t}(\rho \varepsilon)+\frac{\partial}{\partial x_{i}} & \left(\rho \varepsilon u_{i}\right) \\
= & \frac{\partial}{\partial x_{i}}\left[\left(\mu+\frac{\mu_{t}}{\sigma_{\varepsilon}}\right) \frac{\partial \varepsilon}{\partial x_{j}}\right]+\rho C_{1} S_{\varepsilon} \\
& -\rho C_{2} \frac{\varepsilon^{2}}{\kappa+\sqrt{v \varepsilon}}+C_{1_{\varepsilon}} \frac{\varepsilon}{\kappa} C_{3_{\varepsilon}} G_{b} \\
& +S_{\varepsilon} \\
C_{1}=\max \left[0.43, \frac{{ }^{\eta}}{\eta+5}\right]
\end{array}
$$

In this equation, $G \mathrm{k}$ represents the kinetic energy produced due to changes in the velocity gradient is calculated by the following equation:

$$
G_{k}=-\rho \overline{u_{i}^{\prime} u_{j}^{\prime}} \frac{\partial u_{j}}{\partial x_{i}}
$$

$\sigma \mathrm{k}$ and $\sigma \varepsilon$ are the Prantel numbers for $\kappa$ and $\varepsilon$ turbulence and $t$ land $t \varepsilon$ are terms defined by the user. $\mathrm{S}$ is module average rate of strain tensor is defined as follows:

$$
S=\sqrt{2 S_{i j} S_{i j}^{\prime}}
$$

\section{MODELING}

Given the importance of elements around the base of network quality and impact on the results, the network boundary layer around the base are produced. This type of network is not used in numerical analysis scour, because it is difficult to establish the boundary layer in threedimensional geometry. The advantage of this type of network elements control the size of the first layer around the base and determine the orderly growth of layers and number of layers. The first layer to the base height of 5 $\mathrm{mm}$, the growth rate and the number of layers and layers $1 / 02$ and 20 is selected and the size of the boundary layer 0/121487 meters.[35, 36]

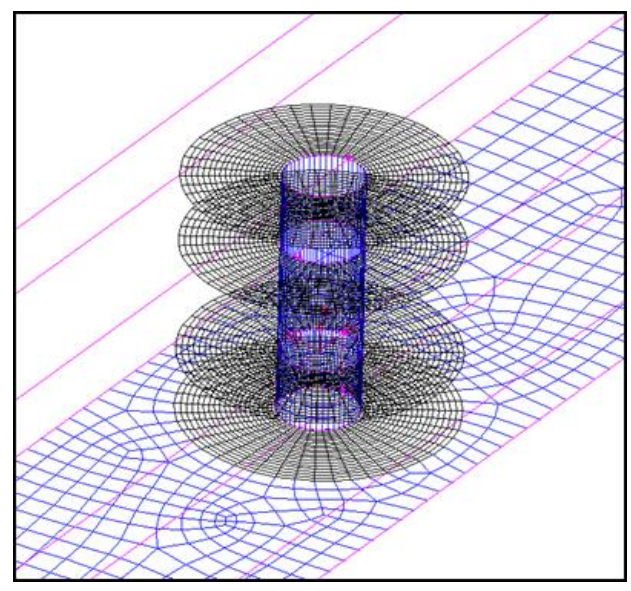

Fig 1: Meshing of substrate surface channel and bridge piers along the boundary layer

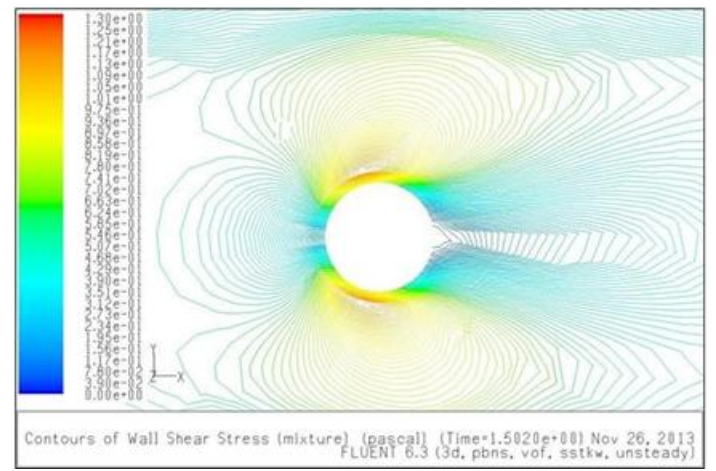

a: Numerical values of shear stress around the base

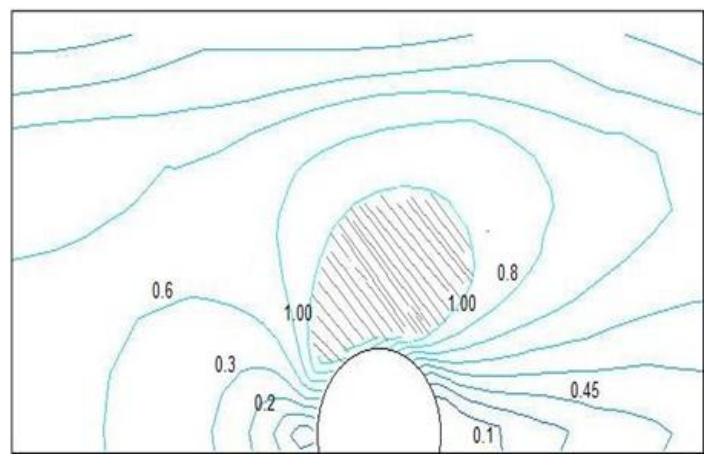

$\mathrm{b}$ : The numerical value of shear stress, ranging from basic scour

Fig 2: Numerical simulation of bridge piers

In this section original model to simulate the bridge pier has split within it. Catia geometry of three- dimensional modeling and computational domain has been done. The following parameters were used for the production of geometry. 


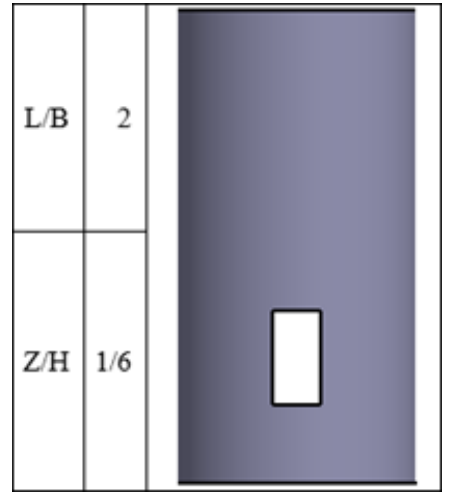

Table 1. gap size

\begin{tabular}{|c|c|}
\hline L & The gap \\
\hline B & Width of the gap \\
\hline Z & Gap between floor of the bed \\
\hline H & Height Paul \\
\hline
\end{tabular}

\section{RESULT}

The boundary conditions is set at the entrance of the Reynolds number equal to 200000 value that indicates a fully turbulent flow. To perform simulations from the powerful software which is used ansys fluent simulation capability is capable of streaming. For modeling turbulence RNG-ke model was used.

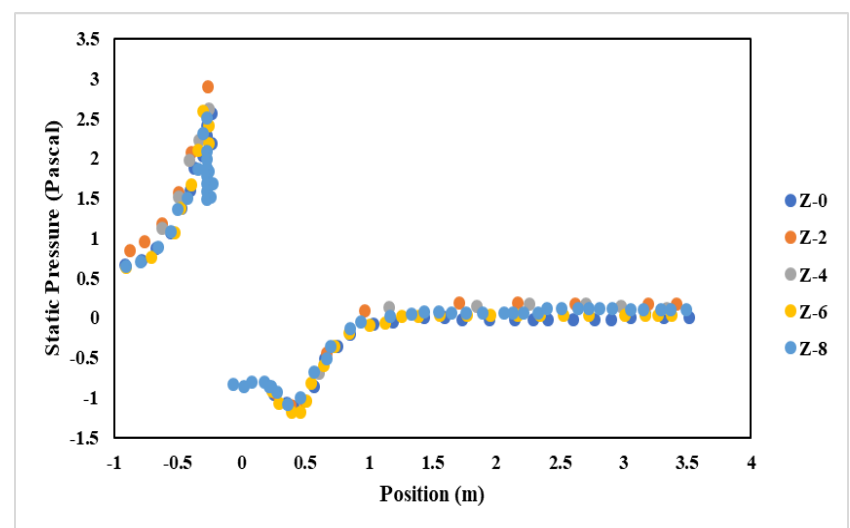

Fig 3: The pressure distributions on longitudinal lines at different heights from the substrate

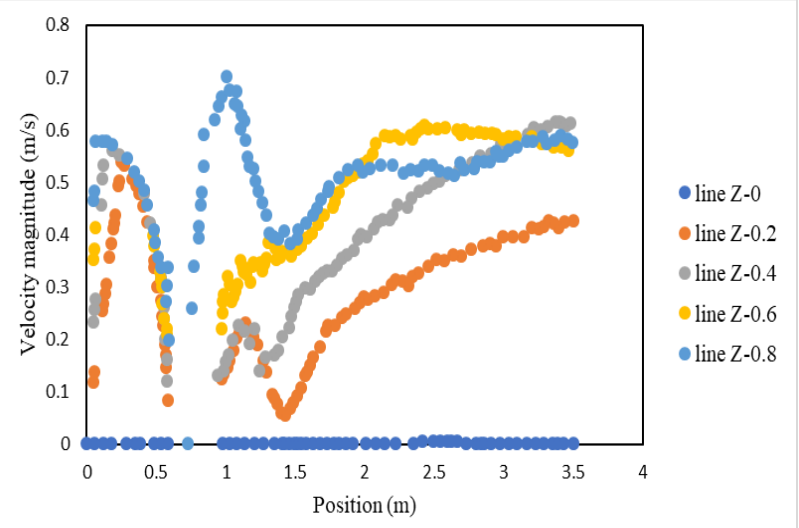

Fig 4: longitudinal lines velocity distribution at different heights from the substrate

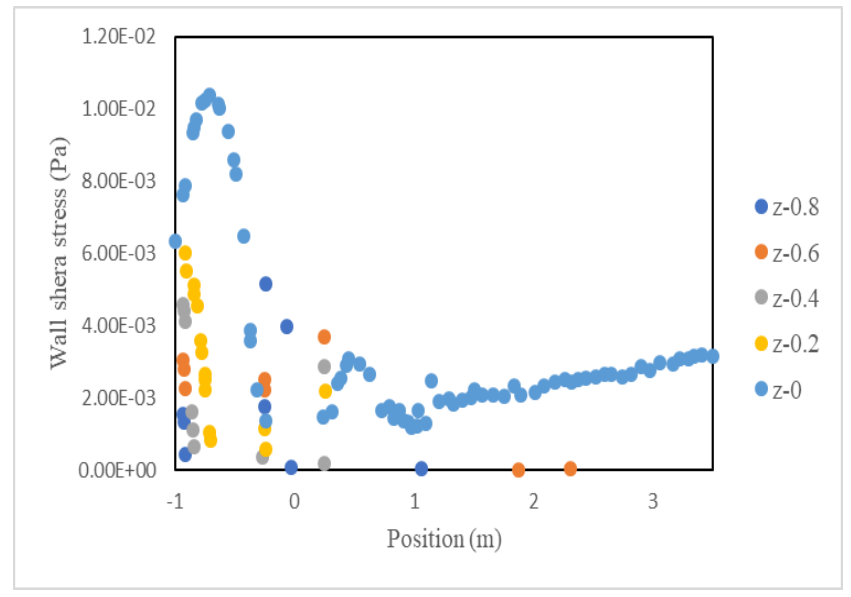

Fig 5: Distribution of shear stress on longitudinal lines at different heights from the the substrate

The shear stress distribution on longitudinal lines at different heights from the the substrate shows. Which, as can be seen from this graph almost at the height of bridge pier where there are gaps shear stress is the highest value and this is an indication that the bridge pier where there are gaps the reduced flow rate Scour the but occur more often and show the shear stress. At the end of the latest models created as another innovation with respect to a proposed recommendation, a hole with a diameter of $5 \mathrm{~cm}$ on the base and at a distance of half a meter from the bed has been created.

\section{CONCLUSION}

In this paper, modeling and simulation in the case of the pier with gaps and without gaps is being investigated. A model without gap is being used to validate the current simulation according to the previous authors. Also it is notable that presence of gap can affect wall shear stress and velocity magnitude as different heights is being considered. It was found that in presence of gaps, shear stress shows its highest value.

\section{REFERENCES}

[1] G.M. Abdel-Aal, Y.A. Mohamed, O. Waheed EDin, M. Elfolly, 2008. Local scour mitigation around bridge piles using protective plate (collar). Scientific Bulletin. Faculty of Engineering. Ain Shames University, Faculty of Engineering, Cairo, Egypt.

[2] G.M. Abdel-Aal, Y.A. Mohamed, 2010. The effect of collar size and shape on scour depth around bridge piers. Scientific Bulletin, Faculty of Engineering, Ain Shames University, Faculty of Engineering, Cairo, Egypt, March.

[3] E.A. Abdelhafiz, 1978. Some flow characteristics in water streams around bridge supports. Unpublished Thesis, Faculty of Engineering, Ain Shams University, Cairo, Egypt. 
[4] F.F.M. Chang, M. Karim, An experimental study of reducing scour around bridge piers using piles, Rep. South Dakota. (1972) 10.

[5] B. Dargahi, Controlling mechanism of local scouring, J. Hydraul. Eng. ASCE 116 (10) (1990) 1197-1214.

[6] E. EL-Ghorab, Reduction of scour around bridge piers using a modified method for vortex reduction, Alexandria Eng. J. 52 (2013) 467- 478.

[7] D. Ferraro, A. Tafarojnoruz, R. Gaudio, A. Cardoso, Effects of pile cap thickness on the maximum scour depth at a complex pier, J. Hydraul. Eng. 139 (5) (2013) 482-491.

[8] L.M. Fotherby, J.S. Jones, The influences of exposed footings on pier scour depths, in: Proceeding of Hydraulics Conference, ASCE, New York, 1993, pp. 22-927.

[9] Hjorth, P., 1975. Studies on the nature of local scour, Dept. Water Res. Eng. Lund Inst. Technol. Bullet. Ser. A, No. 46.

[10] P.A. Johnson, D.A. Dock, Probabilistic bridge scour estimates, J. Hydraul. Eng. ASCE 124 (7) (1998) 750-754.

[11] U. Kothyari, A. Kumar, Temporal variation of scour around circular compound piers, J. Hydraul. Eng. 138 (11) (2012) 945- 957.

[12] Zahabi, H., Torabi, M., Alamatian, E., Bahiraei, M., \& Goodarzi, M. (2018). Effects of Geometry and Hydraulic Characteristics of Shallow Reservoirs on Sediment Entrapment. Water, 10(12), 1725.

[13] V. Kumar, Reduction of scour around bridge pier using protective devices. PhD Thesis, University of Roorkee, Roorkee, India, 1996.

[14] V. Kumar, K.G. Ranga Raju, N. Vittal, Reduction of local scour around bridge piers using slots and collars J, Hydraul. Eng. ASCE 125 (12) (1999) 1302-1305.

[15] B.W. Melville, Local scour at bridge sites, University of Auckland, NEWZEALAND, Ph.D. Thesis, Dept. of Civil eng. Rep. No. 117, 1975.

[16] Torabi, M. A., \& Shafieefar, M. (2015). An experimental investigation on the stability of foundation of composite vertical breakwaters. Journal of Marine Science and Application, 14(2), 175-182.

[17] B.W. Melville, S.E. Coleman, Bridge Scour, Water Resources Publications, 1999.
[18] B.W. Melville, A.C. Hadfield, Use of sacrificial piles as pier scours countermeasures, J. Hydraul. Eng. ASCE 125 (11) (1999)1221- 1224.

[19] B.W. Melville, Y.M. Chiew, Time scale for local scour at bridge piers, J. Hydraul. Eng. ASCE 125 (1) (1999) 59-65.

[20] Y.A. Mohamed, G.M. Abdel-Aal, A.M. Negm, A.A. Fathy, 2008. Effect of triangular collar width on local scour at bridge pier under very low Froude numbers, in: 9th International Congress of Fluid Dynamics and Propulsion, 18-21 December,Alexandria. Egypt.

[21] A.M. Negm, G.M. Abdel-Aal, Y.A. Mohamed, A.A. Fathy, Control of local scour around bridge piers using current deflector, in: Proc. Of 13th IWTC, Hurghada, Egypt, 12-15 March, 2009.

[22] Nordila, Ali M. Thamer, A. Faisal, Y. Badrunnisa, Local scour at wide bridge Piers, Int. J. Eng. Res. Technol. (IJERT) 3(1) (2014).

[23] Paice, R. Hey, The control and monitoring of local scour at bridge piers, Proc. Hydr. Engrg. Conf., ASCE, New York, 1993,pp. 061-1066.

[24] A.J. Raudkivi, R. Ettema, Clear- water scour at cylindrical piers, J. Hydraul. Eng. ASCE 109 (3) (1983) 338-350.

[25] H.W. Shen, V.R. Schneider, S.S. Karaki, Mechanics of local scour, U.S. Department of Commerce, Nat. Bureau of Standards, Inst. Appl. Technol., 1966.

[26] D. Sheppard, B. Melville, H. Demir, Evaluation of existing equations for local scour at bridge piers, J. Hydraul. Eng. 140 (1) (2014) 14-23.

[27] K.K. Singh, D.V.S. Verma, N.K. Tiwari, 1995. Scour protection at circular bridge piers, in: 6th International Symp. on River Sedimentation, New Delhi.

[28] Transit New Zealand, Bridge Inspection and Maintenance Manual, 2001.

[29] A.M. Zarrati, H. Gholami, M.B. Mashahir, Application of collar to control scouring around rectangular bridge piers, J. Hydr. Res. 42 (1) (2004) 97-103.

[30] A.M. Zarrati, M. Nazariha, M.B. Mashahir, Reduction of local scour In the vicinity of bridge pier groups using collars and riprap, J. Hydraul. Eng. ASCE 132 (2) (2006) 154-162.

[31] Torabi, M., Hamedi, A, Alamatian, E., Zahabi, H. (2019). The Effect of Geometry Parameters and 
Flow Characteristics on Erosion and Sedimentation in Channel's Junction using Finite Volume Method. International Journal of Engineering and Management Research (IJEMR), 9(2), 115-123.

[32] Zeidi, S. M. J. and Mahdi, M. [2015], Evaluation of the Physical Forces Exerted on a Spherical Bubble Inside the Nozzle in a Cavitating Flow With an Eulerian/Lagrangian Approach, European J. of Physics, Vol. 136. No. 6, pp 065041; doi:10.1088/0143-0807/36/6/065041.

[33] Zeidi, S. M. J. and Mahdi, M. [2014], Effects of Nozzle Geometry and Fuel Characteristics on Cavitation Phenomena in Injection Nozzles, The 22st Annual International Conference on Mechanical Engineering-ISME 2014, available online at http://www.civilica.com/EnPaper-ISME22_394.htmlhttp://www.civilica.com/EnPaper --ISME22_394.html.

[34] Hamedi, A., Mansoori, A., Shamsai, A., \& Amirahmadian, S. (2014). Effects of End Sill and Step Slope on Stepped Spillway Energy Dissipation. J. Water Sci. Res, 6(1), 1.

[35] Shafaie, M., \& Mostofi, K. H. (2015). RIVER SEDIMENT MONITORING USING REMOTE
SENSING AND GIS (CASE STUDY KARAJ

WATERSHED). International Archives of the Photogrammetry, Remote Sensing \& Spatial Information Sciences, 40.

[36] Hosseini, D., Torabi, M., \& Moghadam, M. A. (2019). Preference assessment of energy and momentum equations over 2D-SKM method in compound channels. Journal of Water Resource Engineering and Management, 6(1), 24-34.

[37] Khoshnevis, S. A., Shahri, S. M. Z., Bina, K., \& Aboutalebi, S. A. (2019). Numerical Study of Sediment Flow Over Bottom Intake Racks With Flow-3D. International Journal of Scientific Research and Management, 7(07), v7i7-ec02.

[38] Ghadami Talkhouncheh, R., Khoshnevis, S. A., Aboutalebi, S. A., Surakanti, S. R., Embedding Wireless Intelligent Sensors Based on Compact Measurement for Structural Health Monitoring Using Improved Compressive Sensing-based Data Loss Recovery Algorithm. International Journal for Modern Trends in Science and Technology, 5(07) July 2019. 